\title{
Interdisciplinarity to reconstruct historical introductions: solving the status of cryptogenic crayfish
}

\author{
Miguel Clavero ${ }^{1, *}$, Carlos Nores ${ }^{2}$, Susanne Kubersky-Piredda ${ }^{3}$ and Alejandro Centeno- \\ Cuadros 4 \\ ${ }^{1}$ Estación Biológica de Doñana-CSIC, Américo Vespucio s.n., 41092 Sevilla, Spain; ${ }^{2}$ Indurot, Universidad de Oviedo, \\ Campus de Mieres, 3006 Mieres, Asturias, Spain; 3Minerva Research Group, Bibliotheca Hertziana, Max Planck \\ Institute for Art History, Via Gregoriana, 28 I-00187 Rome, Italy; ${ }^{4}$ University Pablo de Olavide, Department of \\ Molecular Biology \& Biochemical Engineering, University Pablo de Olavide, Seville, Spain
}

\begin{abstract}
Anciently introduced species can be confounded with native species because introduction pre-dates the first species inventories or because of the loss of the collective memory of the introductions. The term 'cryptogenic species' denotes species of unknown or unclear status (native versus non-native) in a given territory, and disciplinary approaches are often insufficient for solving their true status. Here, we follow an integrative, multidisciplinary approach to solve the status of a cryptogenic species, proposing that building on evidence from multiple disciplines can produce robust and clarifying insights. We undertook an exhaustive review of information on a putatively native crayfish (Austropotamobius italicus) in Spain. The reviewed information included taxonomy, genetics and phylogeography, history, archaeology, linguistics, biogeography, ecology, symbiotic organisms and even gastronomy and pharmacy. The knowledge produced by different scientific disciplines converges to indicate that $A$. italicus is a non-native species in Spain. Historical documents even identify the first introduction event: crayfish were shipped from Italy to Spain in 1588 as a diplomatic gift from Francesco I de' Medici to King Philip II of Spain. Previous discussions on the status of $A$. italicus focussed on inconclusive and often confusing genetic results and excluded the rich and clarifying evidence available from other approaches and disciplines. Interdisciplinarity is an often-invoked but rarely implemented practice in an academic environment that increasingly promotes narrowfocussed specialization. Our review shows that the integration of disciplines can surpass disciplinary approaches in solving scientific controversies. Our results have straightforward implications for strategies to conserve biological diversity in Spain and Europe, urging a debate on the appropriateness of devoting conservation efforts to nonnative species.
\end{abstract}

Key words: biological invasions, Austropotamobius, interdisciplinary science, conservation biology, historical ecology, biogeography, phylogeography, linguistics, Habsburg Spain. 


\section{INTRODUCTION}

Humans have been changing the distribution of other species for millennia, not only driving extinctions (either locally or globally) but also transporting species across biogeographical barriers and introducing them into new environments (Gippoliti \& Amori, 2006; Tella, 2011). The steep increase in the rate of species introduction recorded during the last century and the rise of awareness of the ecological and socioeconomic impacts of several introduced species have probably masked the fact that human-mediated introductions and their impacts are old phenomena (Hulme, 2009; Wilson et al., 2009). The number of introduced species has been underestimated in many regions because the natural or pristine state of systems has been arbitrarily set at the moment of the first visit by biologists or naturalists, while introductions may have taken place earlier (Carlton, 2009; Haydar, 2012). The notion of the nonnativeness of anciently introduced species can be progressively lost, due to deficient intergenerational flow of information about the environment. This information loss can produce a shifting baseline syndrome (Pauly, 1995), by means of which historically introduced species may be perceived as normal and desired, or directly 'native', components of natural systems (Spèziale et al., 2012; Clavero, 2014). The term 'cryptogenic species' was coined to identify species with an uncertain status (native versus non-native) in a given area (Carlton, 1996). Chapman \& Carlton (1991) listed a set of criteria to identify the non-nativeness of species of doubtful status, based mainly on distribution patterns, dispersal capabilities and associations with humans. However, controversies and uncertainties persist for several species (Cunningham, 2008; Chapman et al., 2008). Scientific discussions on the true status of these species can become bitter, and conflicting positions become fixed, especially if an emotional component exists, which is a frequent feature in the field of conservation biology (Noss, 2007).

Some examples of these discussions on the status of cryptogenic species involve European freshwater crayfish (Kouba, Petrusek \& Kozák, 2014), particularly in the Iberian Peninsula (Clavero, 2014; Díez-León et al., 2014). All native European crayfish species have suffered strong declines in the last century, mainly driven by the irruption of the crayfish plague, a disease produced by the oomycete Aphanomyces astaci. The disease was imported into Europe with North American crayfishes, which are asymptomatic carriers of the pathogen (Edgerton et al., 2004; Holdich et al., 2009b). However, it has been generally ignored that some of the declining populations of European crayfishes could themselves have been introduced into originally crayfishfree regions (e.g. Machino et al., 2004). Although they are strict aquatic species, many crayfishes are highly tolerant to desiccation and thus easily transported, a feature that, 
together with their socioeconomic and cultural relevance, has favoured several introductions since the Middle Ages (Swahn, 2004), and possibly since earlier times (Spitzy, 1979). It is well known that human-mediated translocations have had a prominent role in shaping the distributions ranges of European crayfish (Souty-Grosset et al., 2006). However, there are areas, such as England (Holdich, Palmer \& Sibley, 2009a; Kouba et al., 2014) and Spain (Garcia-Berthou, Boix \& Clavero, 2007), where the status of European crayfish species remains controversial. Since native crayfishes are an important target of conservation actions and associated budgets it is relevant to clarify the status of crayfishes in the regions were they are considered cryptogenetic, in order to support or question current conservation strategies.

Here, we follow a multidisciplinary and integrative approach to review the information on putative native crayfish in Spain in order to discern its real status. We assembled evidence from archaeology, history, linguistics, biogeography, genetics and symbiotic organisms to make robust inferences about crayfish status that avoid shortsighted issues associated with disciplinary approaches to the problem. We use the Spanish crayfish example to show that conservation biology can benefit from multidisciplinary approaches to deal with management problems and conflicts. Recent reviews have highlighted the relevance that fields such as history (Szabó \& Hedl, 2011) and palaeozoology (Lyman, 2012) or resources such as museum or herbaria specimens (Johnson et al., 2011) may have for present-day environmental management and conservation challenges. While agreeing with these, we further extend their reasoning to propose that the best, most-informative approach to a problem is to collect cues and evidence from several sources. The claim for the need for interdisciplinarity to address socio-environmental problems is recurrent but its implementation has rarely proved successful (Pooley, Mendelsohn \& Milner-Gulland, 2014). This review aims to be a positive, example-driven call for the integration of knowledge from different scientific disciplines to produce useful environmental management tools and guidelines.

\section{BIOGEOGRAPHY OF AUSTROPOTAMOBIUS CRAYFISHES}

European native crayfishes include five formally described species in the sister genera Astacus (three species) and Austropotamobius (two species) (Machino \& Holdich, 2006). The two Austropotamobius species (A. pallipes and A. torrentium) have complex evolutionary histories and include multiple independent lineages (Grandjean, Frelon-Raimond \& Souty-Grosset, 2002; Trontelj, Machino \& Sket, 2005). The term 'Austropotamobius pallipes complex' is frequently used in the scientific literature (e.g. Grandjean et al., 2002) and includes two lineages that are often treated as independent species, namely $A$. pallipes and $A$. italicus, although the latter has not 
been formally described. Within A. italicus there are also at least four monophyletic groups that are usually considered subspecies (A. i. carinthiacus, A. i. carsicus, $A$. $i$. italicus and A. i. meridionalis) (Pedraza-Lara et al., 2010). Herein, we follow this specific and subspecific subdivision of the A. pallipes complex (Fig. 1).
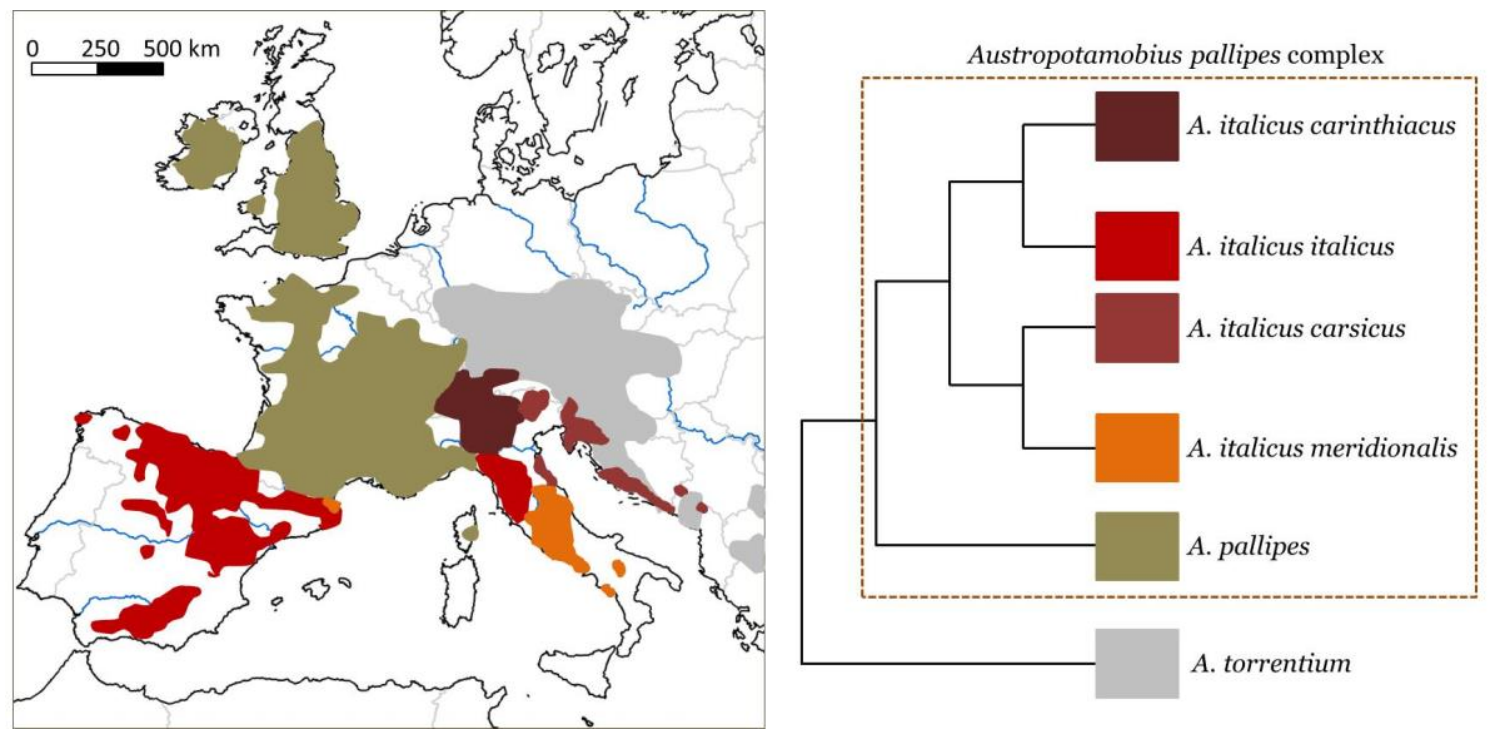

Fig. 1. Distribution of the main Austropotamobius lineages in Western Europe. The phylogenetic tree on the right shows a schematic representation of the hypothesized relationships among lineages, based on Trontelj et al. (2005) and Pedraza-Lara et al. (2010). Distribution areas are based on Souty-Grosset et al. (2006) with modifications following Bertocchi et al. (2008), Cataudella et al. (2010), Scalici \& Bravi (2012) and Vedia \& Miranda (2013).

The distribution of $A$. pallipes and A. italicus is largely separated by the Alps. Due to introductions there are some $A$. pallipes populations in the eastern part of the Po River basin (the largest river system in Italy) and some $A$. italicus populations in France, Austria and Germany (Souty-Grosset et al., 2006; Stefani et al., 2011; Chucholl, Mrugała \& Petrusek, 2015). A. pallipes is also found in Great Britain, Ireland and Corsica as a result of known or probable introductions (Machino et al., 2004; SoutyGrosset et al., 2006; Holdich et al., 2009a; Kouba et al., 2014). A. italicus occupies the Italian Peninsula, the southern slopes of the Alps and the Adriatic coast within the Balkan Peninsula, as well as Spain. The geographic distribution of the different subspecies of $A$. italicus is difficult to define accurately, especially because different lineages can occur sympatrically (e.g. Bertocchi et al., 2008; Cataudella et al., 2010). Schematically, A. italicus meridionalis occupies the southern Italian Peninsula [with one isolated population in north-eastern Iberian Peninsula (Pedraza-Lara et al., 2010); Fig. 1], A. i. carsicus inhabits the Adriatic coast from northern Italy to Albania, A. $i$. 
carinthiacus is found mainly in the western part of the Po river basin and the distribution of the nominal subspecies, A. i. italicus, is shared between the northwestern Italian Peninsula (mainly Tuscany and Liguria) and Spain (Fig. 1). Henceforth, for sake of simplicity and readability, we will use the term crayfish for Austropotamobius italicus italicus. References to other species or subspecies will be made explicit, while the plural "crayfishes" will be used for general allusions to crayfish species.

In a phylogeographic context, the vicariance of $A$. $i$. italicus inhabiting the Italian and Iberian Peninsula could be indicative of recent isolation of two glacial refugia. However, there is an important isolation between the freshwater biotas of the Italian and Iberian peninsulas and those of central Europe, as well as between the two peninsulas (e.g. Italy and Spain do not share a single non-migratory native freshwater fish species). This isolation makes the hypothesis of double glacial refugia highly improbable and suggests human intervention in the distribution of the subspecies (also for the single A. i. meridionalis population in Spain) (Chapman \& Carlton, 1991). Morphological similarity of the Spanish and Italian crayfish was noted as early as the 1960s (Karaman, 1962). Albretch (1983) proposed that crayfish had been introduced to Spain, since their biogeographical patterns would be difficult to explain otherwise. Current knowledge makes the native status of Spanish $A$. $i$. italicus even more difficult to explain, since it would involve a recent expansion through several river basins inhabited by A. pallipes (Fig. 1).

\section{ARCHAEOLOGICAL EVIDENCE}

Environmental biology studies can benefit from archaeological knowledge when addressing long-term ecological processes, and especially those involving human impacts (Briggs et al., 2006; Wolverton \& Lyman, 2012; Sharf, 2014). For example, McKechnie et al. (2014) used archaeological data to show that human exploitation of the Pacific herring (Clupea pallasii) had been sustainable for centuries, until industrial fisheries in the last century drove a huge decline of this species. Information derived from the study of archaeological sites can also be useful to differentiate between native and introduced taxa (Gippoliti \& Amori, 2006) and has been used to determine the temporal patterns of the introduction of rodents to islands (Drake \& Hunt, 2009). The abundant Iberian archaeological record could be informative for assessing the native status of crayfish. However, there are no reports of crayfish remains from archaeological sites in Spain or Portugal from the last few thousand years (A. Morales and M. J. Valente, personal communication). In the deeper past there were freshwater crayfish inhabiting what is today the Iberian Peninsula, as shown by 130 million-year 
old fossils found in central Spain (Garassino, 1997). However, that lineage went extinct at some point and is totally independent from the crayfish populations currently found in the Iberian Peninsula.

Remains of the calcified exoskeletons of crustaceans can become very fragile under some chemical environments (Kenward, 2009) and thus be underrepresented in archaeological sites. However, crustacean remains are more commonly found in archaeological deposits than suggested by the relatively scarce reports in the scientific literature (Gutiérrez Zugasti, 2011). Remains of freshwater crayfishes have been reported from archaeological sites in North America (Hall, 1977) and Europe. The latter include several Neolithic sites in Poland (D. Makowiecki, personal communication) and Romania (Bălăşescu, Moise \& Radu, 2005) and a 16th century site in Strasbourg (Borvon \& Gruet, 2013). Such remains have not been found in the Iberian Peninsula, in contrast with frequent findings of marine crabs (Gutiérrez Zugasti, 2011), some of which are relatively soft-shelled (e.g. Pachygrapsus marmoratus). Although the absence of remains of any given item in archaeological sites is not a proof of the absence of that item in the past (Lyman, 2012) this problem is better approached in terms of plausibility or probabilities. The facts that crayfish remains are found within the historical ranges of several crayfish species and that remains of other crustacean species are found at Spanish sites may not constitute definitive evidence of the absence of crayfish in the Iberian Peninsula in the last millennia but do imply it.

Some authors (e.g. Machino et al., 2004) have reproduced the claim of García de Diego (1947) that a drawing in a ceramic piece from the Celtiberian city of Numantia represents a crayfish, in what would be a proof of the presence of crayfish in the Iberian Peninsula 2000 years ago. However, this supposed evidence can be discarded, because the drawing is so schematic that it could represent any living organism, or even be simply a decorative pattern (see online supporting information, Appendix S1).

\section{HISTORICAL CONTEXT}

The histories of Spain and Italy were tightly linked from the Middle Ages up to the 18th century (Dandelet \& Marino, 2007). By the mid-15th century the Crown of Aragon had become a powerful thalassocracy, ruling over the main western Mediterranean islands as well as over the southern part of the Italian Peninsula. In 1474 the dynastic union between the crowns of Castile and Aragon, through the marriage of the Catholic Monarchs, gave birth to the Kingdom of Spain. Soon after, the Spanish royal family became linked through marriage alliances with the Habsburg family that ruled the Holy Roman Empire. Charles, grandson of the Catholic Monarchs and Emperor Maximilian I, unified the vast domains of his Iberian and Central European families, becoming 
Holy Roman Emperor (as Charles V) and King of Spain (as Charles I). In his final years, and suffering from gout, King Charles divided his reign through abdication, leaving the Spanish part (including Flanders, the Netherlands and the Italian territories) to his older son, Philip II (a progressive abdication that culminated in 1556), and the Holy Roman Empire to his brother Ferdinand (in 1558).

During the first half of the 16th century Spain and France repeatedly fought for control of the Italian Peninsula, in a series of conflicts known as the Italian Wars which ended in 1559 with Philip II as the Spanish king. After the Italian wars the Spanish Kingdom included the Duchy of Milan, the Stato dei Presidi (a new small costal state split from the Republic of Siena) and the Kingdoms of Naples, Sicily and Sardinia. Spain also controlled, both politically and militarily, some Italian territories that did not formally belong to the Spanish Kingdom, including the Duchy of Tuscany and the Republic of Genoa (Dandelet \& Marino, 2007; Fig. 2). The rulers of those territories were semi-vassals of the Spanish Monarchs settled in Madrid and diplomatic, commercial and military exchanges were continuous between Italy and Spain. Further alliances during the late 16th century included the Duchy of Savoy, whose ruler married King Philip II's daughter. The Spanish presence in Italy remained until the War of the Spanish Succession, in the early 18th century, which constituted the end of the Habsburg Monarchy in Spain and the renunciation of all Spanish properties and influences in Italy.

This schematic historical contextualization shows that an important part of the distribution of $A$. italicus, as well as the core of the range of the nominal subspecies (that found in Spain; see Fig. 1), was either part of the Spanish Kingdom or was controlled by Spanish rulers between the mid-16th and the early 18th centuries (Fig. 2). It is therefore plausible that the introduction of crayfish into Spain could have occurred in that period. An introduction in the 18th century, as suggested by Clavero \& Villero (2014), would be less likely regarding the historical context, since in the absence of close relationships with Italian territories it would have been much easier to introduce A. pallipes from neighbouring river basins in France (Galindo, Alonso \& DiéguezUribeondo, 2014). The historical context presented here is rather dynastic biased. This is justified by the fact that royal families and courts have already been signalled as the promoters of crayfish introductions, such as the one that took place in Sweden in the early 16th century (Swahn, 2004). The Habsburg monarchy was probably involved in the introduction of other aquatic species to Spain, such as the common carp (Cyprinus carpio) and the tench (Tinca tinca) (Clavero \& Villero, 2014). As in many royal families, Habsburgs were consummate hunters and fishermen, a family tradition illustrated by the books of Emperor Maximilian I (see Fig. 3) or by the installation of a 
tench fishing pond in the Yuste monastery for the retirement of King Charles I (Hare, 1917).

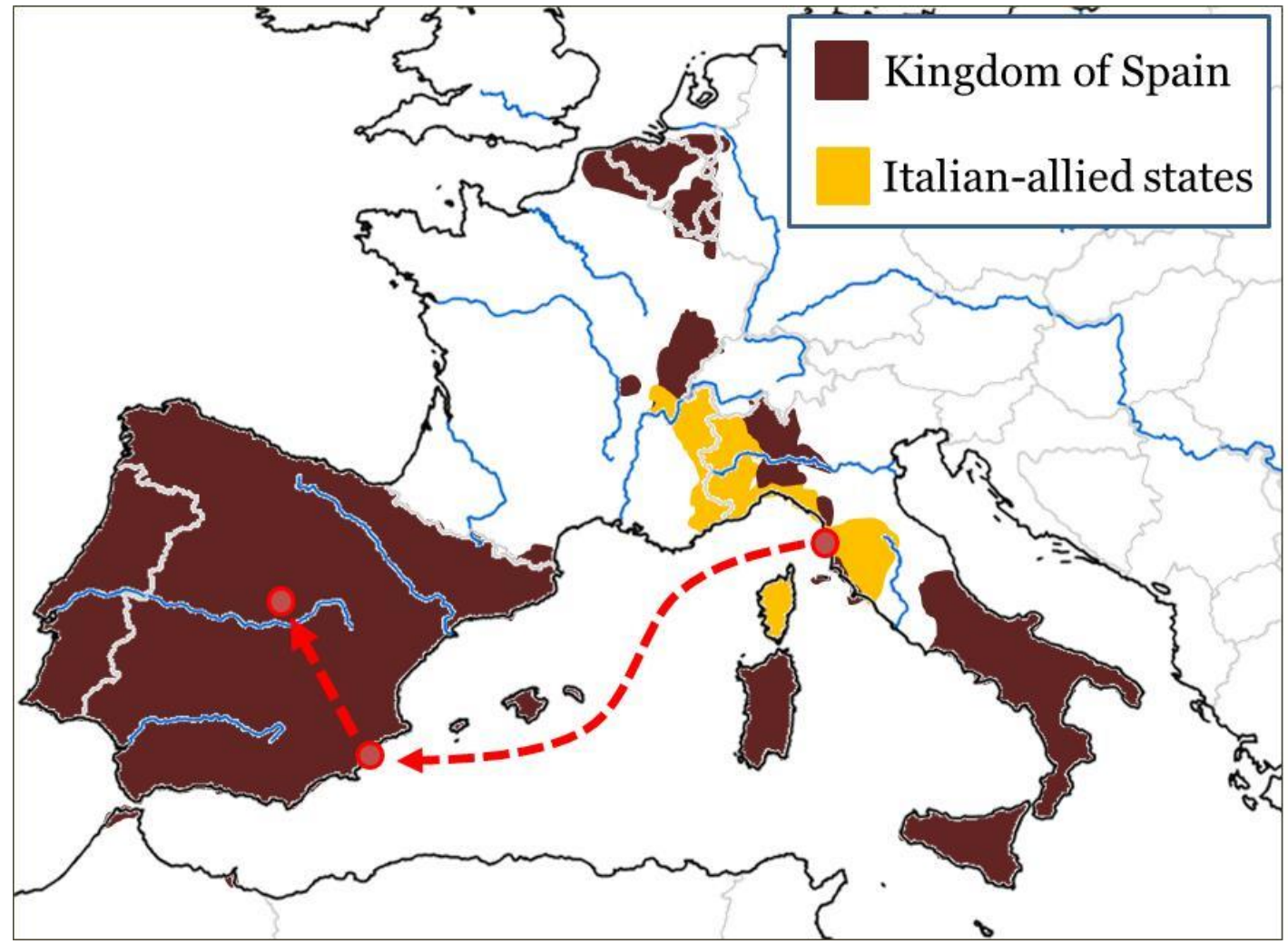

Fig. 2. Territories included in the Kingdom of Spain in the late 16th century, when the crayfish Austropotamobius italicus was introduced into Spain. The Italian states of the Duchy of Savoy, Republic of Genoa and Duchy of Tuscany, Spanish allies in that period, are highlighted in yellow. Arrows mark the approximate journey of the first crayfish known to have been imported to Spain, which were shipped in 1588 from Livorno to Alicante, and then transported to Madrid.

\section{WRITTEN HISTORICAL EVIDENCE}

Written historical testimonies can become relevant sources of information for environmental studies (Szabó, 2014). Historical sources can help to understand ecosystem functioning in a long-term perspective (Jamrichová et al., 2012; Clavero \& Hermoso, 2015) and describe the past distribution of organisms and its dynamics (Josephson, Smith \& Reeves, 2008). Spain has a rich heritage of historical information on biodiversity (Clavero \& Revilla, 2014) that includes several crayfish records (Clavero \& Villero, 2014). However, we start our account of historical written sources with some that do not cite crayfish. 


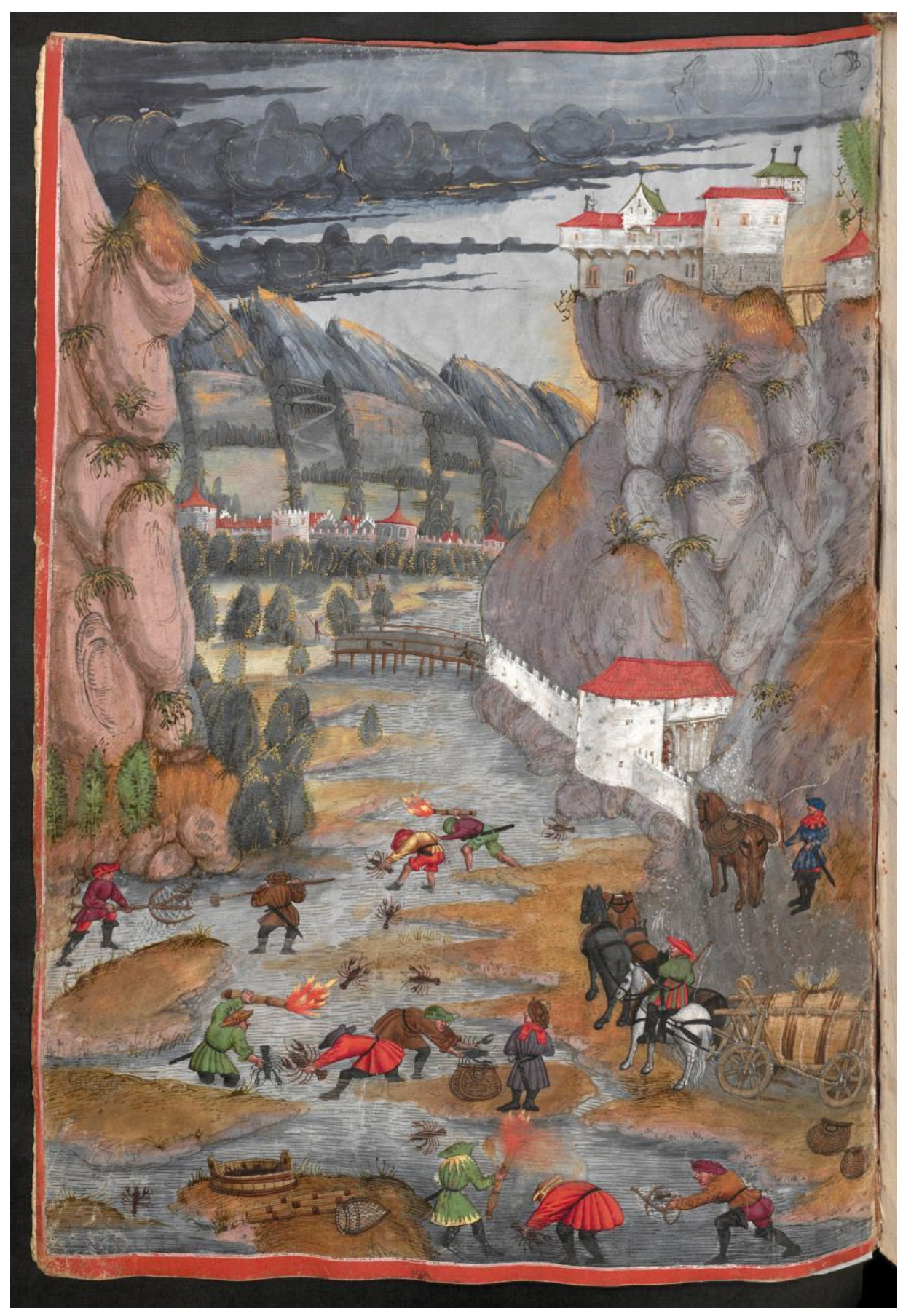

Fig. 3. Crayfish (probably Astacus astacus) fishing in Tyrol (Austria) at the beginning of the 16th century, as illustrated by Jörg Kölderer for the 1504 book Das Tiroler Fischereibuch, attributed to Kaiser Maximilian I. The illustration shows different catch techniques (traps, dip nets and hand catching) as well the carts prepared for the transport of life crayfish. Reproduced with permission from the Austrian National Library (Cod. 7962, p. 100). 
Although scarce, there are some written documents that suggest the historical absence of crayfish from Spain. The Italian naturalist Ulisse Aldrovandi (1522-1605) was the author of an impressive compilation of natural history knowledge, most of which was published posthumously. In the volume devoted to molluscs and crustaceans it is written that crayfish 'abound in streams, rivers and lakes across Europe, but they are not found in Spain, in spite that there is no lack of rivers there' (Aldrovandi, 1606; p. 130). Aldrovandi did know about crayfish distribution outside of Italy, stating that they were abundant in France, Switzerland and Pannonia (probably referring to present-day Austria and Slovenia) and that they existed in North America (which he knew from sailors' accounts). Notably, Aldrovandi had first-hand knowledge of the Spanish environment, since in his youth he travelled through most of the northern half of Spain (described by Baldacci et al., 1907; p. 5), including stopovers in areas known to have crayfish populations in the 17th or 18th centuries (e.g. Valladolid, Burgos, Zaragoza). Aldrovandi was a firm advocator of learning by direct experience, who, as recorded by Baucon (2009, p. 246), explicitly stressed his intention of 'writing only about what I have seen with my own eyes and touched with my own hands'. It is thus difficult to discredit Aldrovandi's report about the absence of crayfish in Spain as an uninformed view. This information was later reproduced (or directly copied) by other authors (Jonstonus, 1650; Sachs, 1665) without further verification, since by that time (as shown below) crayfish had already been brought into Spain.

Historical evidence not noted in previous works (Clavero \& Villero, 2014; Galindo et al., 2014) places the arrival of crayfish in Spain in the late 16th century and relates it directly to Philip II's court. Luis Cabrera de Córdoba (1559-1623) was the son of a servant in the court and, at least since 1581 , directly served the king, both as his righthand man at the El Escorial palace-monastery and as diplomat in several missions (López, 1996). Cabrera de Córdoba is the author of an extended and precise biography of Philip II, largely based on his own experience within the court, with publication beginning in 1619, 20 years after the king's death (Slater, 2007). However, due to polemic issues concerning the Crown of Aragon (the courts of which worked independently from those of Castile), the four-volume publication was censored after the publication of the first volume and the complete work was published only after 250 years (Cabrera de Córdoba, 1876-1877). Cabrera de Córdoba narrates how Philip II promoted expeditions of naturalists and artists to describe and illustrate nature in several regions. Philip II imported to Spain a wide variety of animals, including elephants, rhinoceroses, lions, cheetahs, leopards, camels (which were apparently successfully bred) and ostriches. More relevantly, the king brought to San Lorenzo del Escorial monastery 'even fishes from Flanders, carp and tench, and crayfish from 
Milan' (vol. II, p. 393). This passage was copied by Lorenzo van der Hamen, another almost contemporaneous biographer of Philip II who probably based his book (van der Hamen, 1625) on the censored work of Cabrera de Córdoba. Other historians, like Porreño (1666) and Estrada (1748), also transcribed this same piece of information, although the latter omitted the reference to Milan and placed the origin of carp, tench and crayfish in 'Flanders and Holland'. The mention of Milan as the region of origin of the crayfish could represent a failed introduction, because the A. italicus subspecies found in the Milan area (A. i. carinthiacus) is not present in Spain. However, it is also plausible that Milan was used by Cabrera de Córdoba (and subsequent reproducers of his work) as a general term to refer to Italy. It must be noted that the term Milan is not used in this case to name the city, but the territory of the Duchy of Milan or, in a broader sense, a larger territory including surrounding states.

The Duchy of Tuscany is the most plausible source of crayfish imported to Spain, not only because the $A$. italicus subspecies does match in this case, but also because there is relevant epistolary documentation supporting this hypothesis. These letters show that Gonzalo de Liaño (aka Gonzalillo), a dwarf jester who acted as an agent of Philip II in Italy (Salort \& Kubersky-Piredda, 2006, 2007), had an important role in the transport of crayfish to Spain, as well as in the importation of many other goods, animals and plants. Gonzalo de Liaño transported from Italy to Spain 'paintings and sculptures, reliquaries and devotional images, furniture and textiles, (...) plants, animals, astronomical instruments, medicaments, luxury articles and curiosities' (Salort \& Kubersky-Piredda, 2007, p. 231), a list that Baranda (2009) further specifies mentioning 'curly-plumaged hens, crayfish, Irish dogs, horses, crossbows, a leopard, seeds and bulbs' (p. 10). On May 8th 1583 Gonzalo de Liaño wrote to Francesco I de' Medici, Grand Duke of Tuscany, that King Philip II was interested in receiving crayfish from Italy and had asked him to go to Tuscany and manage the transaction personally (Archivio di Stato di Firenze [ASF], Mediceo del Principato [MDP] 761, f. 292). Later that year, on October 1st, Luigi Dovara, a Tuscan diplomat in Madrid, also wrote to Francesco I de' Medici informing about the visit of Gonzalo de Liaño to Tuscany and the King's desire to have the crayfish in Spain (ASF, MDP 5022, f. 328r; KuberskyPiredda \& Salort, 2011). Philip II had not yet received the crayfish in 1585, as suggested by a letter sent on August 23rd to his daughter Catalina Micaela (newly married to the Duke of Savoy) in which the king noted that 'those who eat crayfish praise them a lot' (Bouza, 2008, p. 125). The crayfish request is again mentioned in a letter from Gonzalo de Liaño to Francesco I de' Medici dated April 5th 1586, stating that the king would be very happy to receive the crayfish alive (ASF, MDP 780, f. 126 / new numbering f. 342). Crayfish were finally shipped from Livorno to Alicante in 1588 , as confirmed by a letter 
sent by Gonzalo de Liaño to Philip II (Archivo General de Simancas, Estado, Leg. 1452, f. 90). The letter stated that the crayfish were under the care of a servant of Francesco I de' Medici who was able to keep them alive for more than three months and was thus confident of carrying them safely to Madrid (see Fig. 2). It must be noted, in relation to the linguistic discussion developed below (Section VI), that in all these letters, as well as in the texts written by Cabrera de Córdoba (1876-1877) and van der Hamen (1625), crayfish are always named with the term gambaro, an adoption of the Italian gambaro or gambero.

The historical documentation makes clear that crayfish were imported into Spain (specifically, brought to the Spanish court) from Tuscany due to the direct interest of King Philip II. It could be argued that this does not prove that there were no native crayfish in Spain, but this seems highly improbable for several reasons. First, historical evidence of crayfish transport match perfectly the current distribution of the nominal A. italicus subspecies (Fig. 1). Second, it is highly implausible that crayfish would have been imported from Italy (implying a long journey including both marine and inland travel, as well as long-lasting diplomatic negotiations) if there were native crayfish in Spain. Third, the fact that crayfish were listed in historical accounts together with exotic organisms, such as leopards, ostriches and carp (e.g. Cabrera de Córdoba, 18761877) reinforces the idea that they were not present in Spain. Similarly, it is also highly improbable that the existence of crayfish in Spain would have passed unnoticed by Philip II. The monarch had a constant curiosity about plants and animals (Bustamante, 1998) and in relation to Natural History 'had in all excellence, and had about all news' (after Cabrera de Córdoba, 1876-1877, vol. II, p. 393). Philip II and his court travelled constantly throughout Castile and Aragon (both for political issues and for hunting and nature-related leisure) and promoted large, unprecedented initiatives for describing the territories within his reign, such as the Relaciones Topográficas in Castile (Clavero \& Revilla, 2014) or the first scientific missions to America (e.g. Goodman, 1983; Bustamante, 1998).

The first mention of crayfish used as food in Spain is in a compilation of recipes made by Francisco Martínez Motiño, who was the first chef in the courts of Philip II and his successors Philip III and Philip IV (Martínez Motiño, 1611). Previous cookbooks, such as the 15th century compilation made Enrique de Villena (edited by Cátedra, 1994) and the work of Ruperto de Nola (Nola, 1529) did not cite crayfish. Crayfish are mentioned again in Spain in 1666, also in relation to the Habsburg monarchy. The account, as reported by Galindo et al. (2014, p. 75), states that 'crayfish are brought from Valladolid for Fridays and fasts and are kept in Valdemorillo [near El Escorial] in a few ponds under the care of a family'. This early report of the presence 
and uses of crayfish in Spain is also the first to provide information about the interbasin transportation of this species. Valladolid and Valdemorillo are in the Douro and Tagus basins, respectively, some $150 \mathrm{~km}$ apart. Popular use of crayfish (i.e. not related to the royal family) is not documented in Spain until the 18th century, a period in which records are concentrated in the Douro and upper Ebro basins (Clavero \& Villero, 2014; Galindo et al., 2014). Crayfish populations were also established in the upper Tagus by the end of the 18th century, as reported by the royal geographer Tomás López in 1773 (Blázquez-Garbajosa, 1984) and the naturalist Joseph Cornide in 1794 (Abascal \& Cebrián, 2009). The arrival of crayfish to the upper Tagus basin must have taken place between the 17th and 18th centuries. There is relatively good information on the environmental features of that same area (and even the same villages) in the late-16th century Relaciones Topográficas, which do not mention crayfish records (Clavero \& Villero, 2014). By contrast, the Relaciones Topográficas from several villages of the upper Tagus referred frequently to freshwater fish species, such as trout, eel, barbels, nase and chub (García-López \& Pérez-Villamil, 2000).

During the 19th century there was an expansion of crayfish in Spain, driven by multiple (probably several hundred) individual introduction events within the country (Clavero \& Villero, 2014). Explicit mentions of introductions, occasionally reporting adverse impacts on fish populations, are reported in the 19th century from several areas across Spain, including Biscay [Ubidea village in Miñano (1826, vol. 9, p. 104)], Cuenca [Trabaque river in Madoz (1846-1850, vol. 15, p. 126)] and Granada [Loja village (Vinsac, 1893)]. These introductions were enthusiastically encouraged by prominent naturalists, such as Mariano de la Paz Graells, who wrote that, due to the lack of shellfish in inland Spain, it is of interest the propagation of crayfish in interior provinces, an operation that is within the reach of everyone' (Graells, 1864, p. 128). Introductions into new areas, often well documented, continued during the 2oth century and the range of crayfish attained its maximum spatial extent in Spain in the 1970s (Clavero \& Villero, 2014). This time point is generally used as the reference scenario in the description of crayfish range in Spain. Crayfish spread was drastically reversed by the arrival of the crayfish plague, associated with the introduction of American crayfish species, which has driven a collapse of crayfish throughout Spain. This collapse involved the disappearance of over $90 \%$ of the populations existing in the 1970s (Alonso, 2011). 


\section{LINGUISTIC EVIDENCE}

The names given to animals and plants are an important component of local ecological knowledge and constitute the only vehicle for its cultural transmission (Kai et al., 2014). Place names related to animals have been used to describe the past status of charismatic species (Aybes \& Yalden, 1995) and some authors have even suggested that the origin of the name of a species can be related to the origin of the species, thus being relevant to understanding its native or introduced status (Brown, 2002). This is based on the assumption that languages that have coexisted with a socioeconomically relevant species would have derived a name for it. Languages that overlap spatially with the native ranges of crayfishes usually have specific words to name them, clearly different from names of other large crustaceans, such as crabs (e.g. gambero versus granchio in Italian or écrevisse versus crabe in French). The English term 'crayfish' is in fact thought to derive from the French écrevisse, possibly reflecting an ancient crayfish introduction into Great Britain (Swahn, 2004; Kouba et al., 2014). In Spanish there is no such linguistic distinction, since crayfish are named cangrejos de río (i.e. river crabs), a pattern that is repeated in Catalonian and Basque languages (cranc de riu and ibai-karramarroa, respectively) (Vedia \& Miranda, 2013). Note that true river crabs (Brachyura such as Potamon spp. of Europe and Northern Africa) are not present in Spain. The term cangrejo (crab) is of ancient use in Spain, recorded at least since the 13th century and already present in the first Spanish-Latin dictionary (Nebrija, 1495). Both Nebrija's dictionary and successive vocabulary compilations (e.g. Nebrija, 1516; Casas, 1570) clearly relate cangrejo to marine crabs (cancer, cancri, carcinos, granchio, paguro in Latin or Italian).

Gambaro (also written gámbaro) is an Italian word, incorporated into Spanish at the begging of the 17th century. It thus seems that crayfish and this name were simultaneously imported from Italy in the late 16th century. Prior to that, use of gambaro by Spanish authors (including in the letters cited previously) always referred to a foreign word. A good example is the Spanish translation of Pedanius Dioscorides' Materia medica made by the Spanish pharmacologist and botanist Andrés Laguna (Laguna, 1555). Laguna states (p. 129) that 'the true crab (...) is a round animal, without tail' and warns about confusion with 'that kind of shrimp that in Greek is called gammaro and astaco, and in all Italy is named gambaro'. It is worth noting that Andrés Laguna lived in Italy between 1545 and 1554, i.e. for the 10 years preceding the publication of his translation of Materia medica. Palet (1604), Vittori (1609), Covarrubias (1611) and Minsheu (1617) all considered gámbaro a Spanish word unmistakably naming crayfish, and all noted the Italian origin of the term. However, gámbaro apparently never succeeded in integrating into popular Spanish usage. In 
spite of its widespread presence in dictionaries gámbaro is very rarely used in direct citizen accounts, which always use the term cangrejo (Clavero \& Villero, 2014). The progressive disuse of the word gámbaro, evident in the early 19th century (RAE, 1803), probably favoured its derivation to naming marine crustaceans (Terreros y Pando, 1787). By the end of the 19th century gámbaro had become a rarely used synonym of shrimp (RAE, 1899). Palet (1604) was the first author to use the Spanish term cangrejo, together with gambaro, in relation to crayfish (as the Spanish translation of the French écrevisse, then written escrevisse). The first formal definition of cangrejo as an animal that lived in rivers (as well as in the sea) was not produced until the 18th century (RAE, 1729).

\section{GENETIC EVIDENCE}

The strongest support for the native status of crayfish in Spain is thought to come from genetic studies (e.g. Díez-León et al., 2014; Kouba et al., 2014). However, the first published phylogenetic analyses on Austropotamobius crayfish indicated that crayfish had been introduced into Spain. This was based on the small or absent genetic variability of Spanish crayfish and their close similarity to Italian samples (Grandjean et al., 2001; Trontelj et al., 2005). Later work found relatively higher genetic diversity as well as private haplotypes of mitochondrial genes, results that were interpreted as support for the native status of crayfish in Spain (Pedraza-Lara et al., 2010; Matallanas et al., 2011). However, as we discuss below, identifying a species as native in a given area cannot exclusively rely either on high genetic diversity or on the existence of private haplotypes. On the other hand, the weak or absent geographic structure regarding the genetic variability of Spanish crayfish, which is independent from the configuration of river basins (e.g. Pedraza-Lara et al., 2010), clearly suggests a humanmediated distribution pattern. Lack of geographic structure has been used previously as an indication of the introduced status of other Austropotamobius populations (Stefani et al., 2011), while the presence of structure has been used to argue for the native status of other organisms (Xavier et al., 2009).

When an introduction event involves a small number of individuals originating from a single source population the resulting population usually experiences a strong reduction in genetic diversity (Sakai et al., 2001). However, introductions do not necessarily follow this pattern, and there are several possible scenarios under which genetic diversity of introduced populations can equal or even exceed that of the native areas (Roman \& Darling, 2007). High genetic diversity can be expected when several individuals are involved in the introduction or introductions are repeated several times (i.e. high propagule pressure) and/or when introduced individuals come from different 
areas within the native range (Kolbe et al., 2004; Lejeusne et al., 2014; Signorile et al., 2014). Both high propagule pressure and diverse source populations are probable features of crayfish introduction in Spain. High propagule pressure is a frequent feature of intentional introductions involving popular species (e.g. Colautti, Grigorovich \& MacIsaac, 2006), as is the case of the arrival of crayfish in Spain. In their native in Tuscany crayfish populations have low intra-population genetic diversity but high inter-population variability (Bertocchi et al., 2008). It is thus perfectly plausible that the relatively high genetic diversity of Spanish crayfish identified by some authors (Pedraza-Lara et al., 2010; Matallanas et al., 2011) could have resulted from an admixture of different Tuscan source populations (see Simon et al., 2011).

Equating haplotype uniqueness to haplotype (and thus population) nativeness is simply wrong. In fact, some of the private haplotypes described for Spanish crayfish populations are exclusive to areas where crayfish are known to have been introduced only after the 18th century. Private haplotypes found in an introduced population can be missing from their native area for different reasons, but particularly due to poor sampling in the native area (Simon et al., 2011; Lejeusne et al., 2014). Differences in sampling effort devoted to Spanish and Italian crayfish populations are evident in recent works. Despite being the most complete study yet published, Pedraza-Lara et al. (2010) include several Spanish populations with many individuals in each and a few Italian populations belonging to the italicus subspecies, all with only a few individuals. It is also possible that private haplotypes present in Spanish populations will not be found in Italy independent of sampling effort, because they no longer exist there due to historical declines and associated genetic erosion. It is arguable, perhaps even probable, that Italian crayfish have lost much of their original genetic diversity. The irruption of the crayfish plague in Spain in the 1970s has led to a loss of over $90 \%$ of crayfish populations (Alonso, 2011). Taking into account that the plague arrived in Italy more than 100 years earlier [the first outbreaks date from 1859 (Aquiloni et al., 2011)], it is likely that a high number of populations may have been lost, together with their genetic signatures (see Koizumi et al., 2012 for a similar example involving crayfish). Horn et al. (2014) analysed mitochondrial control region sequences of Eurasian beaver (Castor fiber) from present and historical samples to describe a huge reduction in genetic diversity associated with human-driven declines. Interestingly, even though the phylogeographical patterns remained rather stable in the last millennium, Horn et al. (2014) did not find any of the 43 haplotypes from historical samples in present-day beavers. Thus, if Eurasian beavers were introduced anywhere 1000 years ago it is highly probable that the haplotypes of the introduced populations would now be unique. Bonett et al. (2007) showed that the correct diagnosis of the status of a 
population (i.e. native or non-native) through genetic analyses is highly dependent on the accurate identification and sampling of possible source populations. If these no longer exist, as is probable for crayfish, the interpretation of results from genetic analyses, especially in terms of the uniqueness of haplotypes, should be made with extreme caution.

The position of haplotypes within haplotype networks is much more relevant to identify or reject native status than their mere uniqueness (Blakeslee, Byers \& Lesser, 2008). Pedraza-Lara et al. (2010; p. 336) show a network of mitochondrial haplotypes in which all Spanish variants (187 individuals in 61 populations) are intermediate between two geographically close Italian populations (only seven individuals analysed). This pattern is difficult to explain by natural distribution shifts, since it would imply multiple migrations from and back to Italy, a remarkably improbable event. A more parsimonious interpretation of the network would involve shared haplotypes in Spain and Italy that were not detected in Italy due to insufficient sampling effort or local extinctions. We collected all available information on cytochrome oxidase subunit I (COI) gene sequences stored in GenBank for Austropotamobius italicus in order to construct haplotype networks and analyse the relationships between Spanish and Italian samples (Fig. 4). We produced two complementary networks, corresponding to two haplogroups of comparable sequences, because different authors had analysed different regions of the COI gene (for full accession codes and methodological details see Appendix S2). Spanish haplotypes occupied intermediate positions between Italian ones in the two networks. Even though most haplotypes described from Spain are not shared with Italy, their position within networks clearly indicates that those 'Spanish' haplotypes are, or at least were, also present in Italy (see Chapman et al., 2008). These 'missing' Italian haplotypes may remain undetected due to incomplete sampling in the Italian Peninsula or may have disappeared there due to the recent widespread crayfish decline.

Thus, far from supporting the native status of crayfish in Spain, the available genetic studies point towards its non-native origin. We feel that it is not necessary (nor even appropriate) to refer to complex biogeographical scenarios to justify genetic patterns that are satisfactorily and much more parsimoniously explained by simple processes, especially when the latter are widely supported by evidence from other approaches. Returning to Fig. 1 in light of this genetic information, a recent natural migration of crayfish from Tuscany to Spain seems more than improbable. 

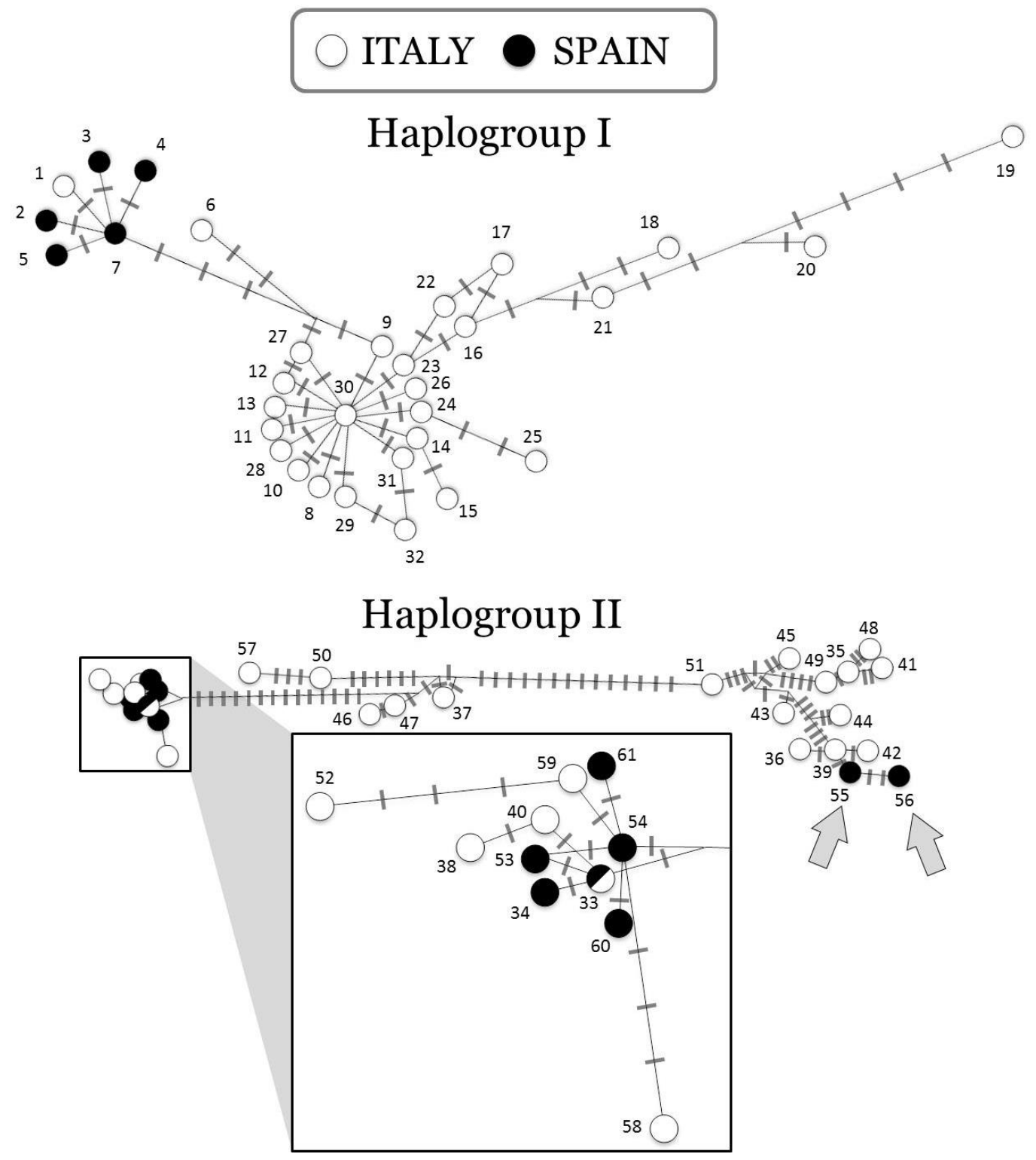

Fig. 4. Median-joining networks of Austropotamobius italicus haplotypes based on two different regions of the cytochrome oxidase subunit I (COI) gene using sequences downloaded from GenBank (haplogroups I and II). See Appendix S2 for full accession codes, identification of individual haplotypes and methods. The arrows in the lower network indicate samples from the single $A$. i. meridionalis population known to occur in Spain (see Fig. 1). Part of the lower network is magnified to ease interpretation of the relationships among haplotypes. Each small crossed line represents one mutational step.

\section{EVIDENCE FROM ASSOCIATED ORGANISMS}

The transport and introduction of a species into a new area acts as a filter for closely associated organisms (parasites, mutualists or symbionts), which may be lost in the process (Richardson et al., 2000; Torchin et al., 2003; Pringle et al., 2009). The removal of these relationships can determine the failure or success of an introduction 
(e.g. Drake, 2003). The study of parasites has been demonstrated to be a useful tool in the identification of the origin of host populations (Criscione, Cooper \& Blouin, 2006), with straightforward applications to invasion biology (Blakeslee et al., 2008).

Crayfishes are hosts to a variety of organisms, from bacteria to metazoans (Edgerton et al., 2002). Branchiobdellidans are an order of leech-like clitellate annelids that are obligate ectosymbionts of crayfishes (Gelder, Gangon \& Nelson, 2002). Some species inhabit preferentially the claws and forelegs, others occupy the gill chamber, while others are microhabitat generalists within the body. The effects of branchiobdellidans on crayfishes can be positive and negative, with the net result difficult to estimate as well as being both context and density dependent (Skelton et al., 2013). Branchiobdellidans are associated with crayfishes across the Holarctic, being found in North America, Europe and Asia. The degree of specificity in the crayfishbranchiobdellid relationship is often quite low; the same branchiobdellid can be found in several crayfish species and a given crayfish can host multiple branchiobdellid species.

All native European branchiobdellid species belong to the genus Branchiobdella (Subchev, 2014), while the introductions of North American crayfish species have led to the arrival of associated species in genera Cambarincola and Xirogoniton (Gelder, Parpet \& Quaglio, 2012; Vedia et al., 2014). Native branchiobdellidans have been found in all areas with Austropotamobius crayfish populations, except for Spain and Ireland (Subchev, 2014) an absence that fits well with the introduced status of Austropotamobius crayfish in these two territories. Crayfishes are highly resistant to temperature extremes, dehydration and low oxygen tension (e.g. Demers et al., 2006) and can thus be easily transported alive [e.g. Aldrovandi (1606) wrote about living crayfish being transported across Europe by cart in the 16th century]. However branchiobdellids are much less tolerant and may not be able to survive a long transportation (Gelder et al., 2012). It is more than plausible that crayfish travelling from western France to Ireland in the Middle Ages (Gouin et al., 2003) and from Italy to Spain in the late-16th century (see above) could have lost their branchiobdellid load. By contrast, it would be very difficult to explain why native branchiobdellidans are absent from Spain if the Iberian Peninsula had been naturally colonized by crayfish. As an example, branchiobdellidans were found in more than $90 \%$ of the crayfish examined in central Italy (Gherardi et al., 2002). 


\section{MULTIDISCIPLINARITY AND THE STATUS OF AUSTROPOTAMOBIUS}

\section{ITALICUS}

Our review shows that a human-mediated introduction is the only parsimonious explanation for the presence of crayfish in Spain. Previous studies using narrower approaches were less categorical in their suggestions (Albrecht, 1983; Clavero \& Villero, 2014) or even found putative support for the native status of Spanish crayfish (PedrazaLara et al., 2010; Kouba et al., 2014). However, our multidisciplinary approach leaves little room for doubt. Many independent and plausible facts and patterns must be contradicted to support the native status of crayfish in Spain. After a careful review, the knowledge produced by different scientific disciplines combines to support the categorization of crayfish as a non-native species in Spain. The reviewed information included taxonomy, genetics and phylogeography, history (dynastic, military and biographic), linguistics, biogeography, ecology, symbiotic organisms and even gastronomy and pharmacy. Other studies have successfully addressed environmental issues using an interdisciplinary approach, as shown by the collaboration between a plant ecologist and a historian to show that wildfire recurrence in north-eastern Spain was similar in the 13-14th centuries and in the second half of the 2oth century (Lloret \& Marí, 2001). More recently Jamrichová et al. (2012) combined palaeopalynology and archival historical sources to describe the long-term dependency of a forest ecosystem on human management. These studies provide examples of how the integration of disciplines can surpass individual-discipline approaches in producing new understanding and generating problem-solving tools.

Since many of the problems currently faced by our societies are complex, interconnected and embedded in a dynamic environment, research, and particularly applied research, is expected to become increasingly interdisciplinary in the future (Briggs et al., 2006; Lyall \& Meagher, 2012). Although calls for interdisciplinarity in environmental research have been frequent over the last decades, the development of interdisciplinary research projects and agendas faces many challenges (Lau \& Pasquini, 2008; Pooley et al., 2014). Problems have been identified at multiple levels, from research planning and funding schemes to project design and individual perceptions. Solutions to overcome such difficulties are being proposed and tested (Bridle et al., 2013), but the real change needed is probably related to the attitudes of researchers. In spite of the frequent proclamation of the benefits of interdisciplinarity, academic structures continue to promote narrowly focussed specialization (Szabó \& Hedl, 2013). Education and research should focus on promoting a transdisciplinary attitude (Kockelmans, 1979), which would ideally translate to creative and inquisitive 
researchers open to alternative views and willing to transgress boundaries (Augsburg, 2014).

The clear identification of $A$. italicus as a non-native species in Spain has conservation implications both at the European and Spanish scale, since it raises the question of whether it is reasonable to devote conservation efforts to introduced species (e.g. Clavero, 2015). The white-clawed crayfish sensu lato (i.e. A. pallipes and $A$. italicus) is included in Annex II of the European Habitats Directive, and thus it is mandatory for European Union member states to designate Special Areas of Conservation for this species. This mandate affects Spain, Portugal and Ireland, where Austropotamobius crayfishes are introduced species. Kouba et al. (2014) already signalled the irony of having Ireland as the 'Isle of Hope' for the conservation of Austropotamobius pallipes. Conserving crayfishes in areas where they have been introduced could be justified through the lens of a managed relocation (e.g. Richardson et al., 2009). However, the huge conservation efforts devoted to preserving the last Spanish Austropotamobius populations (e.g. Alonso, 2011) highlight the long-term failure of a once-successful relocation experience, casting doubts about the appropriateness of maintaining this conservation strategy. Societies may also value on trying to reverse the declines of highly appreciated non-native species (Clavero, 2014) even producing specific legislation to protect these species (Speziale et al., 2012). For example, the Portuguese oyster (Crassostrea angulata), long thought to be native in Europe (actually formally described in Europe) and now known to have been introduced from Asia some 500 years ago (Carlton, 2009), is threatened in southern Europe by the expansion of its equally Asian congeneric $C$. gigas. In spite of the nonnative status of the Portuguese oyster some authors have discussed the need to implement conservation measures for this declining bivalve (e.g. Huvet et al., 2000). Formally protected species introduced long ago include the dingo (Canis lupus dingo) in Australia (Allen \& Fleming, 2012) and the crested porcupine (Hystrix cristata) in Italy (Mori, Sforzi \& Di Febbraro, 2013). Despite these examples, it is hardly disputable that focussing conservation efforts and actions on non-native species should be, at least, questioned (Clavero, 2015). In Europe, it would seem beneficial to remove the compulsory nature of the Habitat Directive implications in territories where an annexlisted species is not native (such as for crayfish in Spain). This legal change would open the path for regional-level discussions on the value of having non-native species as high-priority conservation targets. 


\section{CONCLUSIONS}

(1) An integrative review of multiple lines of evidence robustly identifies Autropotamobius italicus as an introduced species in the Iberian Peninsula. Our interdisciplinary approach overcomes many of the limitations of previous singlediscipline analyses of the status of $A$. italicus in Spain.

(2) We identified the date of the first recorded introduction event (1588), which was related to the Habsburg Spanish monarchy, already known to have imported other species into Spain.

(3) Environmental problems are becoming more complex and interconnected, but they are addressed by an increasingly specialized and narrow-focussed scientific community. Our review is an example of the benefits of the integration of approaches from different scientific disciplines to address environmental issues, in order to produce more robust understanding as well as useful tools and guidelines.

(4) Strategies aimed at the conservation of biodiversity should be rethought in light of our results both in Spain and Europe. European putative native crayfish species are currently mandatory conservation priorities in areas where they are in fact introduced species. Changes should be introduced in European environmental legislation to allow the adaptation of conservation strategies at the local and regional levels.

\section{ACKNOWLEDGEMENTS}

We thank J. T. Carlton, M. Delibes, P. Pons and an anonymous reviewer for their helpful comments. A. Morales, M. J. Valente, I. Gutiérrez Zugasti, A. Borvon, D. Makowiecki, Q. Goffete and S. Hamilton-Dyer provided information about crayfish (or their absence) in archaeological sites. M.C. was funded by a Ramón y Cajal contract from the Spanish Government.

\section{REFERENCES}

Abascal, J. M. \& Cebrián, R. (2009). Los viajes de José Cornide por España y Portugal de 1754 a 1801. Real Academia de la Historia. Madrid.

ALBRECHT, H. (1983). Besiedlungsgeschichte und ursprünglich holozäne Verbreitung der europäischen Flußkrebse (Decapoda: Astacidae). Spixiana 6, 61-77.

Aldrovandi, U. (1606). De reliquis animalibus exanguibus. Libri IV. De mollibus, crustaceis, testaceis, et zoophytis. Babtistam Bellagambam, Bologna.

Allen, B. L. \& Fleming, P. J. S. (2012). Reintroducing the dingo: the risk of dingo predation to threatened vertebrates of western New South Wales. Wildlife Research 39, 35-50. 
Alonso, F. (2011). Austropotamobius italicus (Faxon, 1914). In Atlas y Libro Rojo de los Invertebrados amenazados de España (Especies Vulnerables) (eds. J. R. VERDÚ, C. Numa, E., Galante), pp. 651-672. Ministerio de Medio Ambiente, Medio Rural y Marino, Madrid.

Aquiloni, L., MARTin, M. P., Gherardi, F. \& DiÉGuez-URIBEOndo, J. (2011). The North American crayfish Procambarus clarkii is the carrier of the oomycete Aphanomyces astaci in Italy. Biological invasions 13, 359-367.

AYBES, C. \& YALDEN, D.W. (1995). Place-name evidence for the former distribution and status of wolves and beavers in Britain. Mammal Review 25, 201-226.

Augsburg, T. (2014). Becoming transdisciplinary: the emergence of the transdisciplinary individual. World Futures 7o, 233-247.

BĂLĂŞESCU, A., MOISE, D., \& RADU, V. (2005). The palaeoeconomy of Gumelniţa communities on the territory of Romania. Cultură şi civilizaţie la Dunărea de Jos 22, 167-200.

Baldacci, A., DE Toni, E., Frati, L., Ghigi, A., Gortani, M., Morini, F., Ridolfi, A. C. \& SORBELLI, A. (1907). Intorno alla vita e alle opere di Ulisse Aldrovandi. Libreria Treves di L. Beltrami, Bologna.

BANDELT, H. J. \& ForsteR, P. (1997). The myth of bumpy hunter-gatherer mismatch distributions. American Journal of Human Genetics 61, 980-983

BARANDA, N. (2009). Las cartas de un gentilhombre de Placer: Gonzalo de Liaño, "trompeta de esta corte". Lectura y Signo 4, 9-33.

BAUCON, A. (2009). Ulisse Aldrovandi (1522-1605): The study of trace fossils during the Renaissance. Ichnos 16, 245-256.

Bertocchi, S., Brusconi, S., Gherardi, F., Grandjean, F. \& Souty-GRosset, C. (2008). Genetic variability of the threatened crayfish Austropotamobius italicus in Tuscany (Italy): implications for its management. Fundamental and Applied Limnology 173, 153-164.

Blakeslee, A. M., BYers, J. E. \& LeSSER, M. P. (2008). Solving cryptogenic histories using host and parasite molecular genetics: the resolution of Littorina littorea's North American origin. Molecular Ecology 17, 3684-3696.

BlázQuez-GarbajosA, A. (1984). Las relaciones topográficas de D. Tomás López. Pueblos de la provincia de Guadalajara (1760-1795). Wad-Al-Hayra 11, 97-132.

BonetT, R. M., Kozak, K. H., Vieites, D. R., Bare, A., Wooten, J. A., \& Trauth, S. E. (2007). The importance of comparative phylogeography in diagnosing introduced species: a lesson from the seal salamander, Desmognathus monticola. BMC Ecology 7, 7. 
Borvon, A. \& GRUET, Y. (2013). Les vestiges d'Écrevisses (Crustacés Décapodes d'eau douce) de la latrine 1060 de Strasbourg (67), «Rue de Lucerne - rue du Jeu de Paume », XVIe siècle. In Strasbourg (67), «Rue de Lucerne - rue du Jeu de Paume ». Rapport final d'opération (ed. M. WERLÉ) Pôle d'Archéologie Interdépartemental Rhénan, Sélestat (in prep).

BouzA, F. (2008). Cartas de Felipe II a sus hijas. Ed. Akal, Madrid.

Bridle, H., VRieling, A., CARdillo, M., ARAYA, Y. \& Hinojosa, L. (2013). Preparing for an interdisciplinary future: A perspective from early-career researchers. Futures $\mathbf{5 3}$, 22-32.

Briggs, J. M., Spielmann, K. A., SchaAfSma, H., Kintigh, K. W., Kruse, M., MoRehouse, K. \& SchOllmeYER, K. (2006). Why ecology needs archaeologists and archaeology needs ecologists. Frontiers in Ecology and the Environment, 4, 180-188.

BRown, D. (2002). The foulmart: what's in a name? Mammal Review, 32, 145-149.

Bustamante, J. (1998). La empresa naturalista de Felipe II y la primera expedición científica en suelo americano: La creación del modelo expedicionario renacentista. In Felipe II (1527-1598): Europa y la monarquía católica (ed. J. M. MILLÁN), vol. 4, pp. 39-59. Universidad Autónoma de Madrid, Madrid.

CAbrera de Córdoba, L. (1876-1877). Felipe Segundo, Rey de España. Aribau y cia. Madrid.

CARLtON, J. T. (1996). Biological invasions and cryptogenic species. Ecology 77, 16531655 .

CARlton, J. T. (2009). Deep invasion ecology and the assembly of communities in historical time. In Biological invasions in marine ecosystems (eds. G. RILOV \& J. A. CROOKS), pp. 13-56, Springer-Verlag, Berlin.

CASAS, C. DE LAS (1570). Vocabulario de las dos lenguas toscana y castellana. Casa de Francisco Aguilar, Sevilla.

Cataudella, R., Paolucci, M., Delaunay, C., Ropiquet, A., Hassanin, A., Balsamo, M., \& GRANDJEAN, F. (2010). Genetic variability of Austropotamobius italicus in the Marches region: implications for conservation. Aquatic Conservation: Marine and Freshwater Ecosystems 2o, 261-268.

CÁtedra, P. M. (1994). Obras completas de Enrique de Villena. Vol. 1. Turner Libros, Madrid.

Chapman, J. W. \& CARlton, J. T. (1991). A test of criteria for introduced species: the global invasion by the isopod Synidotea laevidorsalis (Miers, 1881). Journal of Crustacean Biology 11, 386-400.

Chapman, J. W., Blakeslee, A. M., Carlton, J. T. \& Bellinger, M. R. (2008). Parsimony dictates a human introduction: on the use of genetic and other data to 
distinguish between the natural and human-mediated invasion of the European snail Littorina littorea in North America. Biological Invasions 10, 131-133.

Chucholl, C., Mrugafa, A. \& Petrusek, A. (2015). First record of an introduced population of the southern lineage of white-clawed crayfish (Austropotamobius 'italicus') north of the Alps. Knowledge and Management of Aquatic Ecosystems 416: 10.

Clavero, M. (2014). Shifting baselines and the conservation of non-native species. Conservation Biology 28, 1434-1436.

Clavero, M. (2015). Non-native species as conservation priorities: response to DíezLeón et al. Conservation Biology 29, 957-959.

Clavero, M., \& Hermoso, V. (2015). Historical data to plan the recovery of the European eel. Journal of Applied Ecology, in press.

Clavero, M. \& Revilla, E. (2014). Biodiversity data: Mine centuries-old citizen science. Nature 510, 35 .

Clavero, M. \& Villero, D. (2014). Historical ecology and invasion biology: long-term distribution changes of introduced freshwater species. Bioscience 64, 145-153.

ColautTi, R. I., Grigorovich, I. A. \& MacisaAC, H. J. (2006). Propagule pressure: a null model for biological invasions. Biological Invasions 8, 1023-1037.

Covarrubias, S. (1611). Tesoro de la lengua castellana o española. Luis Sánchez impresor, Madrid.

Criscione, C. D., COOPER, B. \& Blouin, M. S. (2006). Parasite genotypes identify source populations of migratory fish more accurately than fish genotypes. Ecology 87, 823828.

Cunningham, C. W. (2008). How to use genetic data to distinguish between natural and human-mediated introduction of Littorina littorea to North America. Biological Invasions 10, 1-6.

DANDElet, T. J., \& MARINO, J. A. (2007). Spain in Italy. Politics, Society and Religion 1500-170o. Koninklijke Brill, Leiden.

Demers, A., Souty-Grosset, C., Trouilhe, M. C., Füreder, L., Renai, B., \& Gherardi, F. (2006). Tolerance of three European native species of crayfish to hypoxia. Hydrobiologia 560, 425-432.

DíEZ-LEÓn, M., MirandA, R., ARiÑo, A. H. \& GaliCia, D. (2014). Setting priorities for existing conservation needs of crayfish and mink. Conservation Biology 29, 599-601.

DRAKE, J. M. (2003). The paradox of the parasites: implications for biological invasion. Proceedings of the Royal Society of London. Series B: Biological Sciences 270, S133S135. 
DRAKE, D. R. \& HUNT, T. L. (2009). Invasive rodents on islands: integrating historical and contemporary ecology. Biological Invasions 11, 1483-1487.

Edgerton, B. F., Evans, L. H., StePhens, F. J. \& Overstreet, R. M. (2002). Synopsis of freshwater crayfish diseases and commensal organisms. Aquaculture 2o6, 57-135.

Edgerton, B. F., Henttonen, P., Jussila, J., Mannonen, A. R. I., PaAsonen, P., Taugbøl, T., Edsman, L. \& Souty-Grosset, C. (2004). Understanding the causes of disease in European freshwater crayfish. Conservation Biology 18, 1466-1474.

Estrada, J. A. (1748). Población General de España. Tomo primero. Imprenta del Mercurio, Madrid.

Galindo, F. J., Alonso, F. \& DiÉGuez-URIBEOndo, J. (2014). Cangrejo de río: la ciencia sí es aval de su carácter nativo. Quercus 342: 74-79.

GARAssino, A. (1997). The macruran decapod crustaceans of the Lower Cretaceous (Lower Barremian) of Las Hoyas (Cuenca, Spain). Atti della Società italiana di Scienze naturali e del Museo civico di Storia naturale in Milano 137, 101-126.

Garcia-Berthou, E., Boix, D. \& Clavero, M. (2007). Non-indigenous animal species naturalized in Iberian inland waters. In Biological invaders in inland waters: profiles, distribution, and threats (ed. F. GHERARDI), pp. 123-140. Invading Nature: Springer Series in Invasion Ecology, Springer, Dordrecht.

GARCíA DE DIEGO, R. (1947). Estilización del pez en la cerámica celtíbera de Numancia. Montes 16, 357 - 364 .

García-LóPEZ, J. C. \& PÉREZ-Villamil, M. (2000). Relaciones topográficas de la provincia de Guadalajara. CD-ROM. Diputación Provincial, Guadalajara.

Gelder, S. R., GANGON, N. L. \& NELSON, K. (2002). Taxonomic considerations and distribution of the Branchiobdellida (Annelida:Clitellata) on the North American continent. Northeastern Naturalist 9, 451-468.

GELDER, S. R., PARPET, J. F. \& QUAGLIO, F. (2012). First report of two North American branchiobdellidans (Annelida: Clitellata) or crayfish worms on signal crayfish in Europe with a discussion of similar introductions into Japan. Annales de LimnologieInternational Journal of Limnology 48, 315-322.

Gherardi, F., Cenni, F., Crudele, G. \& Mori, M. (2002). Infestation rate of branchiobdellids in Austropotamobius pallipes italicus from a stream of Central Italy: preliminary results. Bulletin Français de la Pêche et de la Pisciculture 367, 785-792.

GIPPOLITI, S. \& AMORI, G. (2006). Ancient introductions of mammals in the Mediterranean Basin and their implications for conservation. Mammal Review, 36, 3748.

GoOdman, D. (1983). Philip II's patronage of science and engineering. British Journal for the History of Science 16, 49-66. 
Gouin, N., Grandjean, F., Pain, S., Souty-Grosset, C. \& Reynolds, J. (2003). Origin and colonization history of the white-clawed crayfish, Austropotamobius pallipes, in Ireland. Heredity 91, 70-77.

Graells, M. P. (1864). Manual práctico de Piscicultura. D.E. Aguado, Madrid.

Grandjean, F., Frelon-Raimond, M. \& Souty-Grosset, C. (2002). Compilation of molecular data for the phylogeny of the genus Austropotamobius: one species or several? Bulletin Français de la Pêche et de la Pisciculture 367: 671-680.

Grandjean, F., Gouin, N., Souty-Grosset, C. \& DiéGuez-Uribeondo, J. (2001). Drastic bottlenecks in the endangered crayfish species Austropotamobius pallipes in Spain and implications for its colonization history. Heredity 86, 431-438.

GuTIÉRREZ ZugASTI, F. I. (2011). The use of echinoids and crustaceans as food during the Pleistocene-Holocene transition in Northern Spain: methodological contribution and dietary assessment. The Journal of Island and Coastal Archaeology 6, 115-133.

HALl, H. J. (1977). A paleoscatological study of diet and disease at Dirty Shame rockshelter, southeast Oregon. Miscellaneous Papers of the Idaho State University Museum of Natural History 8, 1-38.

HARE, C. (1917). A great emperor. Charles V, 1519-1558. Charles Scribner's Sons, New York.

HAYDAR, D. (2012). What is natural? The scale of cryptogenesis in the North Atlantic Ocean. Diversity and Distributions 18, 101-110.

Holdich, D. M., Palmer, M. \& Sibley, P. J. (2009a). The indigenous status of Austropotamobius pallipes (Lereboullet) in Britain. In Crayfish Conservation in the British Isles (eds. J. BRICKLAND, D. M. HOLDICH, E. M. IMHOFF), pp. 1-11. Proceedings of a conference held on $25^{\text {th }}$ March 2009 in Leeds, UK.

Holdich, D. M., Reynolds, J. D., Souty-Grosset, C. \& Sibley, P. J. (2009b). A review of the ever increasing threat to European crayfish from non-indigenous crayfish species. Knowledge and Management of Aquatic Ecosystems 394-395, 11.

Horn, S., Prost, S., Stiller, M., Makowiecki, D., Kuznetsova, T., Benecke, N., Pucher, E., Hufthammer, A. K., Schouwemburg, C., Shapiro, B. \& Hofreiter, M. (2014). Ancient mitochondrial DNA and the genetic history of Eurasian beaver (Castor fiber) in Europe. Molecular Ecology 23, 1717-1729.

Hulme, P. E. (2009). Trade, transport and trouble: managing invasive species pathways in an era of globalization. Journal of Applied Ecology 46, 10-18.

Huvet, A., Lapegue, S., Magoulas, A. \& Boudry, P. (2000). Mitochondrial and nuclear DNA phylogeography of Crassostrea angulata, the Portuguese oyster endangered in Europe. Conservation Genetics 1, 251-262. 
IACONElli, M. \& Cianchi, R. (publication unknown) Phylogeography and genetic structure of the freshwater crayfish Austropotamobius italicus. GenBank.

Jamrichová, E., Szabó, P., Hédl, R., Kuneš, P., Bobek, P. \& Pelánková, B. (2012). Continuity and change in the vegetation of a Central European oakwood. The Holocene 23, 46-56.

Johnson, K. G., Brooks, S. J., Fenberg, P. B., Glover, A. G., James, K. E., Lister, A. M., Michel, E., Spencer, M., Todd, J. A., VAlsami-Jones, E., Young, J. R. \& STEWART, J. R. (2011). Climate change and biosphere response: unlocking the collections vault. Bioscience 61, 147-153.

Jonstonus, J. (1650). Historiae naturalis de exanguibus aquaticis Libri IV. Matthaei Meriani, Frankfurt.

Josephson, E., SMith, T. D. \& ReEves, R. R. (2008). Historical distribution of right whales in the North Pacific. Fish and Fisheries 9, 155-168.

KaI, Z., Woan, T. S., Jie, L., Goodale, E., Kitajima, K., BaGCHI, R. \& Harrison, R. D. (2014). Shifting baselines on a tropical forest frontier: extirpations drive declines in local ecological knowledge. PLoS one 9, e86598.

KARAMAN, M. S. (1962). Ein beitrag zur systematik der Astacidae (Decapoda). Crustaceana 3, 173-191.

KENWARD, H. K. (2009). Northern Regional Review of Environmental Archaeology: Invertebrates in Archaeology in the North of England. English Heritage, York.

KOCKELMANS, J. (1979). Why interdisciplinarity? In Interdisciplinarity and higher education (ed. J. KocKELMANS), pp. 123-160. Pennsylvania State University, University Park.

Koizumi, I., Usio, N., Kawai, T., Azuma, N. \& Masuda, R. (2012). Loss of genetic diversity means loss of geological information: the endangered Japanese crayfish exhibits remarkable historical footprints. PLoS one 7, e33986.

Kolbe, J. J., Glor, R. E., Schettino, L. R., Lara, A. C., Larson, A. \& Losos, J. B. (2004). Genetic variation increases during biological invasion by a Cuban lizard. Nature 431, 177-181.

Kouba, A., Petrusek, A. \& KozÁk, P. (2014). Continental-wide distribution of crayfish species in Europe: update and maps. Knowledge and Management of Aquatic Ecosystems 413, 05 .

KubERSKY-PiredDA, S. \& SALORT, S. (2011). Travels of a Court Jester: Gonzalo de Liaño, art agent at the court of King Philip II of Spain. In Double agents. Cultural and political brokerage in Early Modern Europe (eds. KeBluseK, M. \& Nolduss, B. V.), pp. 213-232. Bill, Leiden. 
Laguna, A. (1555) Pedacio Dioscorides Anazarbeo. Acerca de la materia medicinal y de los venenos mortiferos. Hans Laet, Antwerp.

LAU, L. \& PASQuinI, M. (2008). 'Jack of all trades'? The negotiation of interdisciplinarity within geography. Geoforum 39, 552-560.

Lejeusne, C., Saunier, A., Petit, N., Béguer, M., Otani, M., Carlton, J. T., Rico, C. \& GREEN, A. J. (2014). High genetic diversity and absence of founder effects in a worldwide aquatic invader. Scientific Reports 4, 5808.

LLORET, F. \& MARÍ, G. (2001). A comparison of the medieval and the current fire regimes in managed pine forests of Catalonia (NE Spain). Forest Ecology and Management 141, 155-163.

LóPEZ, A. G. (1996). El Escorial, en Luis Cabrera de Córdoba. In Literatura e imagen en El Escorial: actas del Simposium (ed. CAMPOS, F. J.), pp. 667-682. Real Centro Universitario Escorial-María Cristina, El Escorial.

LyALL, C. \& MEAGHER, L. R. (2012). A masterclass in interdisciplinarity: Research into practice in training the next generation of interdisciplinary researchers. Futures 44, 608-617.

LYMAN, R. L. (2012). A warrant for applied palaeozoology. Biological Reviews 87, 513525 .

MAChino, Y., FÜREDER, L., LAURENT, P. J. \& PetUTChNig, J. (2004). Introduction of the white-clawed crayfish Austropotamobius pallipes in Europe. Berichte des Naturwissenschaftlich-Medizinischen Vereins in Innsbruck 91, 187-212.

MACHINO, Y. \& HolDICH, D. M. (2006). Distribution of crayfish in Europe and adjacent countries: updates and comments. Freshwater Crayfish 15, 292-323.

MADOZ, P. (1846-1850) Diccionario geográfico-estadístico-histórico de España y sus posesiones de ultramar. 16 vols. P. Madoz and L. Sagasti, Madrid.

MARTínez MotiÑo, F. (1611). Arte de cozina, pastelería, vizcochería y conservería. Luis Sánchez, Madrid.

Matallanas, B., Ochando, M. D., Vivero, A., Beroiz, B., Alonso, F. \& Callejas, C. (2011). Mitochondrial DNA variability in Spanish populations of A. italicus inferred from the analysis of a COI region. Knowledge and Management of Aquatic Ecosystems 401, 30.

Matallanas, B., De Vivero, A., Beroiz, B., Alonso, F., Ochando, M. D. \& Callejas, C. (publication unknown) Genetic relationships of white-clawed crayfish (Austropotamobius italicus) populations as determined by nuclear and mitochondrial markers. GenBank.

MCKeChnie, I., LePofsky, D., Moss, M. L., Butler, V. L., ORCHARD, T. J., COUPLAND, G., Foster, F., Caldwell, M. \& Lertzman, K. (2014). Archaeological data provide 
alternative hypotheses on Pacific herring (Clupea pallasii) distribution, abundance, and variability. Proceedings of the National Academy of Sciences 111, E807-E816.

MinsheU, J. (1617). Vocabularium Hispanicum Latinum et Anglicum copiossisimun, cum nonnullis vocum millibus locupletatum, ac cum Linguae Hispanica Etymologijs. Joanum Browne, London.

MiÑano, S. (1826-29). Diccionario geográfico-estadístico de España y Portugal. 11 vols. Imprenta Pierart-Peralta, Madrid.

Mori, E., SForZI, A. \& Di Febbraro, M. (2013). From the Apennines to the Alps: recent range expansion of the crested porcupine Hystrix cristata L., 1758 (Mammalia: Rodentia: Hystricidae) in Italy. Italian Journal of Zoology 8o, 469-480.

NEBRIJA, A. (1495). Vocabulario español-latino. Salamanca.

NEBRIJA, A. (1516). Vocabulario de romance en latín. Juan Varela de Salamanca, Sevilla.

NOLA, R. DE (1529). Libro de guisados, manjares y potajes intitulado libro de cozina. Miguel de Eguía, Logroño.

Noss, R. (2007). Values are a good thing in conservation biology. Conservation Biology 21, 18-20.

PALET, J. (1604). Diccionario muy copioso de la lengua española y francesa. Dictionaire tres ample de la langue espagnole et fraçoise. Matthieu Guillemor, Paris.

PAulY, D. (1995). Anecdotes and the shifting baseline syndrome of fisheries. Trends in Ecology and Evolution 10, 430.

Pedraza-Lara, C., AldA, F., Carranza, S. \& DoAdrio, I. (2010). Mitochondrial DNA structure of the Iberian populations of the white-clawed crayfish, Austropotamobius italicus italicus (Faxon, 1914). Molecular Phylogenetics and Evolution 57, 327-342.

Pooley, S. P., Mendelsohn, J. A. \& Milner-Gulland, E. J. (2014). Hunting down the chimera of multiple disciplinarity in conservation science. Conservation Biology $\mathbf{2 8}$, 22-32.

PORREÑo, B. (1666) Los dichos y hechos del rey Phelipe II, llamado con justa razón el prudente. Francisco Coppens Impressor, Brussels.

Pringle, A., Bever, J. D., Gardes, M., PARrent, J. L., Rillig, M. C. \& KliRonomos, J. N. (2009). Mycorrhizal symbioses and plant invasions. Annual Review of Ecology, Evolution, and Systematics 4o, 699-715.

RAE (1729). Diccionario de la lengua castellana. Compuesto por la Real Academia Española. Tomo segundo. Que contiene la letra C. Imprenta de Francisco del Hierro, Madrid. 
RAE (1803). Diccionario de la lengua castellana compuesto por la Real Academia Española, reducido a un tomo para su más fácil uso. Quarta edición. Viuda de Ibarra, Madrid.

RAE (1899). Diccionario de la lengua castellana por la Real Academia Española. Décima tercia edición. Imprenta de los señores Hernando y compañía, Madrid.

Richardson, D. M., Allsopp, N., D'antonio, C. M., Milton, S. J. \& Rejmanek, M. (2000). Plant invasions- the role of mutualisms. Biological Reviews 75, 65-93.

Richardson, D. M., Hellmann, J. J., Mclachlan, J. S., SaX, D. F., Schwartz, M. W., Gonzalez, P., Brennan, E. J., CAmacho, A., Root, T. L., Sala, O. E., Schneider, S. H., Ashe, D. M. Clark, J. R., EARly, R., EtTERSON, J. R., et al. (2009). Multidimensional evaluation of managed relocation. Proceedings of the National Academy of Sciences 106, 9721-9724.

ROMAN, J. \& DARLING, J. A. (2007). Paradox lost: genetic diversity and the success of aquatic invasions. Trends in Ecology and Evolution 22, 454-464.

SACHS, P. J. (1665). Gammarologia. Frankfurt and Leipzig.

Sakai, A. K., Allendorf, F. W., Holt, J. S., Lodge, D. M., Molofsky, J. With, K. A., Baughman, S., Cabin, R. J., Cohen, J. E., Ellstrand, N. C., McCauley, D. E., O’Neil, P., PARker, I. M., Thompson, J. M. \& Weller, S. G. (2001). The population biology of invasive species. Annual Review of Ecology and Systematics 32, 305-332.

SAlORT, S. \& KubERSKY-PireddA, S. (2006). Art collecting in Philip II's Spain: the case of Gonzalo de Liaño, king's dwarf and gentle-man of the bedchamber: part I. The Burlington Magazine 148, 660-665.

SAlORT, S. \& KubERSKY-PireddA, S. (2007). Art collecting in Philip II's Spain: the case of Gonzalo de Liaño, king's dwarf and gentle-man of the bedchamber: part II. The Burlington Magazine 149, 224-231.

SCALICI, M. \& BRAVI, R. (2012). Solving alpha-diversity by morphological markers contributes to arranging the systematic status of a crayfish species complex (Crustacea, Decapoda). Journal of Zoological Systematics and Evolutionary Research 50, 89-98.

SCHARF, E. A. (2014). Deep time: the emerging role of archaeology in landscape ecology. Landscape Ecology 29, 563-569.

Signorile, A. L., Wang, J., LurZ, P. W. W., Bertolino, S., Carbone, C. \& Reuman, D. C. (2014). Do founder size, genetic diversity and structure influence rates of expansion of North American grey squirrels in Europe? Diversity and Distributions 2o, 918-930 Simon, A., Britton, R., Gozlan, R., VAn Oosterhout, C., Volckaert, F. A. \& HÄNFLING, B. (2011). Invasive cyprinid fish in Europe originate from the single introduction of an admixed source population followed by a complex pattern of spread. PLOS ONE 6, e18560. 
Skelton, J., Farrell, K. J., Creed, R. P., Williams, B. W., Ames, C., Helms, B. S., StOECKel, J. \& BROWN, B. L. (2013). Servants, scoundrels, and hitchhikers: current understanding of the complex interactions between crayfish and their ectosymbiotic worms (Branchiobdellida). Freshwater Science 32, 1345-1357.

SLATER, J. (2007). History as an ekphrastic genre in early modern Spain. MLN $\mathbf{1 2 2}$, 217-232.

Speziale, K., Lambertucci, S., Carrete M. \& Tella, J. L. (2012). Dealing with nonnative species: what makes the difference in South America. Biological Invasions 14, 1609-1621.

Souty-Grosset, C., Holdich, D. M., Nöel, P. Y., Reynolds, J. D. \& Haffner, P. (2006). Atlas of Crayfish in Europe. Museum National d'Histoire Naturelle, Paris.

SPITZY, R. (1979). The prehistoric man as a possible crayfish transplantor. Freshwater Crayfish 4, 221-225.

Stefani, F., Zaccara, S., Delmastro, G. B. \& Buscarino, M. (2011). The endangered white-clawed crayfish Austropotamobius pallipes (Decapoda, Astacidae) east and west of the Maritime Alps: a result of human translocation? Conservation Genetics 12, 5160 .

SubChev, M. (2014). The Genus Branchiobdella Odier, 1823 (Annelida, Clitellata, Branchiobdellida): a Review of its European Species. Acta Zoologica Bulgarica 66, 520.

SwAHn, J. Ö. (2004). The cultural history of crayfish. Bulletin Français de la Pêche et de la Pisciculture 372, 243-262.

SZABÓ, P. (2014). Historical ecology: past, present and future. Biological Reviews, in press.

SzABÓ, P. \& HEDL, R. (2011). Advancing the integration of history and ecology for conservation. Conservation Biology 25, 680-687.

SzABÓ, P. \& HEDL, R. (2013). Grappling with Interdisciplinary Research: Response to Pooley. Conservation Biology 27, 1484-1486.

TAmura, K., Dudley, J., NEI, M. \& Kumar, S. (2007). MEGA4: Molecular Evolutionary Genetics Analysis (MEGA) software version 4.o. Molecular Biology and Evolution 24, 1596-1599

TELLA, J. L. (2011). The unknown extent of ancient bird introductions. Ardeola 58, 399-404.

TERREROS Y PANDO, E. (1787). Diccionario castellano con las voces de ciencias y artes y sus correspondientes en tres lenguas: francesa, latina e italiana. Tomo segundo. Viuda de Ibarra, Madrid. 
Thompson, J. D., Higgins, D. G. \& Gibson, T. J. (1994). ClUSTALW: improving the sensitivity of progressive multiple sequence alignment through sequence weighting, position-specific gap penalties and weight matrix choice. Nucleic Acids Research 22, 4673-4680

Torchin, M. E., LAfFerty, K. D., Dobson, A. P., Mckenzie, V. J. \& KuRis, A. M. (2003). Introduced species and their missing parasites. Nature 421, 628-630.

TrontelJ, P., Machino, Y. \& Sket, B. (2005). Phylogenetic and phylogeographic relationships in the crayfish genus Austropotamobius inferred from mitochondrial COI gene sequences. Molecular Phylogenetics and Evolution 34, 212-226.

VAN DER HAMEN, L. (1625). Don Felipe el Prudente, segundo deste nombre, Rey de las Españas y Nuevo Mundo. Viuda de Alonso Martin, Madrid.

VEDIA, I. \& MIRANDA, R. (2013). Review of the state of knowledge of crayfish species in the Iberian Peninsula. Limnetica 32, 269-286.

Vedia, I., Oscoz, J., Rueda, J., Miranda, R., García-Roger, E. M., Baquero, E. \& GELDER, S. R. (2014). An alien ectosymbiotic branchiobdellidan (Annelida: Clitellata) adopting exotic crayfish: a biological co-invasion with unpredictable consequences. Inland Waters 5, 89-92.

VInSAC, J. (1893). Notas carcinológicas. Actas de la Sociedad Española de Historia Natural 22, 70.

VITTORI, G. (1609). Tesoro de las tres lenguas francesa, italiana y española. Thesor des trois langues françiose, italienne et espagnolle. Philip Albert \& Alexandre Pernet, Geneva.

Wilson, J. R., Dormontt, E. E., Prentis, P. J., Lowe, A. J. \& Richardson, D. M. (2009). Something in the way you move: dispersal pathways affect invasion success. Trends in Ecology and Evolution 24, 136-144.

Wolverton, S. \& LyMAN, R. L. (eds.) (2012). Conservation biology and applied zooarchaeology. University of Arizona Press.

XAVIER, R., SANTOS, A. M., LIMA, F. P. \& BRANCO, M. (2009). Invasion or invisibility: using genetic and distributional data to investigate the alien or indigenous status of the Atlantic populations of the peracarid isopod, Stenosoma nadejda (Rezig 1989). Molecular Ecology 18, 3283-3290.

Zaccara, S., Stefani, F. \& CROSA, G. (2005). Diversity of mitochondrial DNA of the endangered white-clawed crayfish (Austropotamobius italicus) in the Po River catchment. Freshwater Biology 50, 1262-1272. 